Senyshyn, O., Kundytskyj, O., \& Klepanchuk, O. (2019). An Index Analysis for the Assessment of the Competitiveness of Food Products in Ukraine. Journal of Competitiveness, 11(2), 130-143. https://doi. org/10.7441/joc.2019.02.09

\title{
AN INDEX ANALYSIS FOR THE ASSESSMENT OF THE COMPETITIVENESS OF FOOD PRODUCTS IN UKRAINE
}

- Oksana Senyshyn, Oleksandr Kundytskyj, Olha Klepanchuk.

\begin{abstract}
This scientific article deals with the use of index analysis for the assessment of the competitiveness of national food products within the system of international agri-food production competitiveness. The primary objective of this scientific article is the calculation of the actual comparative advantages of separate countries of the world in foreign trade in agri-food products using the RCAij (relative trade advantages) index. First, the pattern of international competitiveness of the most important agri-food items exported by Ukraine is determined on the basis of calculation of RCAij, following which measures are proposed to raise the level of competitiveness of these national food products within world food markets. Calculations of the RCAij indices of revealed comparative advantage (RCA) have shown that Ukrainian agri-food industry in 2017 moved into third place in the level of international competitiveness. Comparative advantages, i.e. calculations using the actual comparative advantages index RCAij, were determined. These calculations demonstrate that the greatest comparative advantages in 2017 were shown by Argentina (RCAij=4.503), New Zealand (RCAij=4.361), Brazil (RCAij=2.558), and Chile (RCA$\mathrm{ij}=1.324)$. These results show the great share of agri-food exports as compared to the overall exports of goods of the said countries, each with comparatively small volumes of food imports. The value of the index of actual comparative advantages of Ukraine reached 1.131, a result that demonstrates insignificant comparative advantages within the world market, which we link with the average volume of food products imports.
\end{abstract}

Keywords: competitiveness of food products, food exports and imports, index of revealed comparative advantage, index of relative trade advantages, relative import penetration JEL Classification: C15, F11, L66, O57, Q17

Received: December, 2018

1st Revision: March, 2019

Accepted: April, 2019

\section{INTRODUCTION}

In the age of world economic globalization, the development of foreign economic relations and trade is an exceptionally important factor for the functioning of the national economy of any country, as it is not only of economic, but of considerable political importance as well. The chal- 
lenges associated with the globalization of agri-food system predetermine acceleration rates of the growth of world trade in food products as compared with the growth rate of production of agricultural and food products. In our opinion, one of the important problems in the process of integration of Ukraine into the world economic community is the saturation of the internal market with international competitive agri-food products and the expansion of exports.

At the same time, not only the growth of export potential of the food sector of Ukraine, but also improvement of the structure of exports should be regarded as the priority trend of strategic development at the stage of forming relations with the world market. Most important of all is Ukraine's access to new markets with its own competitive agri-food products that meet requirements of the international standards.

The information and reference basis of this research are legislative and legal normative acts of Ukraine and other countries of the world dealing with foreign trade in goods and services; international documents; analytical and statistical materials of the State Statistical Service of Ukraine, Food and Agricultural Organization of the United Nations, United States Department of Agriculture, European Commission, Research Institute of Organic Agriculture (FiBL), WTO Annual Report; along with scientific works of international and Ukrainian scientists including periodical publications and, finally, the results of personal observations.

The methodological framework of this research is based on an index analysis that combines elements of the system of indices for the assessment of national food product competitiveness in the system of international agri-food production competitiveness, namely: the index of revealed comparative advantage RCAi (which assesses the competitiveness of the agri-food sector compared with other branches of the economy), the index of actual comparative advantages RCAij (which was used to calculate Ukraine competitiveness in international agri-food production compared with other countries of the world), indices of relative trade advantages RTAij (which assess the behavior patterns of separate food commodities in terms of international competitiveness), the index of relative export competitiveness RXAij, as well as the relative import penetration index RMPij. Methods of theoretical analysis, system and analytical methods of generalization as well as grouping methods helped to identify measures in the context of raising the level of competitiveness of national food products within world markets.

\section{THEORETICAL BACKGROUND: VIEWS OF SCIENTISTS ON THE METHODS OF ASSESSMENT OF COMPARATIVE ADVANTAGES OF A COUNTRY IN TERMS OF FOOD PRO- DUCTION}

It should be noted that the works of many scientists and economists have been dedicated to studies of competitiveness of national food products within world markets (Andriychuk, 1990; Chaudhary, 2016; Danylyshyn, 2008, Dejneko et al., 2007, Dolishniy et al., 2006; Granabetter, 2016; Hubenko, 2003; Kohls \& Uhl, 1990; Kolkova, 2018; Kyrylyuk, 2009; Mayovecj, 2006; Majstro, 2005; Paskhaver, 2001; Sabluk et al., 2008; Scott \& Vollrath, 1992; Suchanek \& Kralova, 2018). Owing to their efforts, theoretical and methodological foundations for the study of this 
problem there have been established, and a number of methodological and applied problems pertaining to the formation of competitive agri-food market along with improvement of the economic mechanism of its functioning have been resolved.

As studies of these problems have shown, problems of international competition are of overriding priority. The formation of the global agri-food system as a result of the enhancement of international cooperation and division of labor, interaction and the globalization of national commodity systems in the sphere of production and sale of agricultural and food products have become the main driving force and the goal of the development of all individual national productive forces within the agri-food complex.

The present authors describe the competitiveness of national agri-food products as consisting of the aggregate of competitive advantages manifested in the world market in comparison with the relevant exponents-indicators (factors) of other competitor-countries.

In the scientific literature, different theoretical and methodological approaches have emerged to examine the core factors (exponents, indicators) that form the competitive advantages of a certain country in the production of a particular type of food product, and how this calculation can stimulate the development of international trade. One of the most common methods for measuring competitive advantages is the comparison of the actual prices of food and agricultural products, the results of which can serve as indicators of comparative efficiency of the production of goods by producers in various countries. Elements such as the profitability of production, level of labor productivity, strategic planning efficiency, effectiveness of agricultural unit management, ability to react rapidly to the needs and demands of agri-food market, etc. may serve as factors to help measure competitive advantages of the agri-food products.

A study of the various ideas and interpretations of scientists and economists regarding the factors that shape the competitive advantages of a certain country in the production of one or another kind of food or agricultural product suggests that the most contemporary approach is the analysis of exports and imports of agricultural and food products. Accordingly, the larger the country's export of a particular commodity is, the more competitive advantages this country maintains.

The well-known Ukrainian scientist Hubenko (2003) claims that a country's competitive edge in the international market is determined by a certain set of components that he identifies as the "national rhomb", the components of which consist of: factor conditions, i.e. those specific factors (skilled labor or infrastructure) required for the successful competition in this field; conditions of demand, i.e. the demand in the domestic market for products or services offered by the given industry; allied and supporting industries, i.e. the presence or absence in the country of the allied and supporting industries competitive in the international market; the company's strategy, its structure and competitors, i.e. the conditions in the country that determine the process of establishment and management of the firms along with the nature of competition in the national market; and state policy, which includes the regulation of the national market.

A review of the scientific literature has shown that almost all indicators of competitiveness are formed on the basis of information on foreign trade volumes, which are used mainly for international comparisons, but in certain situations can also be used to determine the competitiveness 
of separate regions calculated for a particular product or a product group. Bearing in mind that competitiveness is a relative category, indices based on relative values (such as market share, export volume, etc.) provide little information on the precise competitive position of the industry or product within the national economy. What may prove more informative are indices based on the comparison of one sector with another, i.e. so-called competitiveness indices. The most often used indicators by foreign scientists include the Export Advantage Index (RXA), Relative Import Penetration Index (RMP), Relative Trade Advantage Index (RTA), Relative Export Advantage Index (RTA) and Revealed Comparative Advantage Index (RCA) (Chaudhary, 2016; Granabetter, 2016).

Considerable attention has been focused on studies of the complex methodology of competitiveness in academic articles by Chaudhary (2016) and Granabetter (2016) regarding the calculation of the index of the revealed comparative advantage of RCA. Analyses of such indices can foster examinations of the state of competition of a separate sector in comparison with other sectors of the country's economy, i.e. with the volume of exports and imports entered into the indicator. In the opinion of these scientists, it is customary to use the RCA index in the international economy as well for the calculation of the export potential of a industry or sector.

Taken together, these indices are combined in the so-called index analysis of assessment of the competitiveness of food production or agricultural products of the country in general. We fully support the position of the well-known scientists and are convinced that agri-food production, that today, along with other sectors and complexes of the economy, determines the export profile of the country, has sufficient competitive advantages to remain one of the leading branches of international specialization of the country. Therefore, the pressing problem is the problem of determination of the current international competitiveness of national agri-food products, as well as that of certain goods of traditional Ukrainian agri-food exports.

\section{RESEARCH OBJECTIVE AND METHODOLOGY}

The primary objective of this scientific article is calculation of actual comparative advantages of separate countries of the world in foreign trade in agri-food products using index RCAij and determination of the pattern of international competitiveness of products that appeared to be the backbone of agri-food items of export of Ukraine on the basis of calculation of the indices of relative trade advantages RTAij, proceeding from which to propose measures in the context of raising the level of competitiveness of national food products in the world food markets.

\subsection{Method for calculating index of the revealed comparative advantage RCAi as the tool for a comprehensive assessment of agri-food sector competitiveness}

Assessing holistically competitiveness of the agri-food sector in comparison with other sectors of the Ukrainian economy, we find it expedient to use the method of calculation of the index of the revealed comparative advantage of RCAi, using statistical information on the volumes of foreign trade of the country in separate groups of goods. The above said concept examines with the state of competition in a separate sector in comparison with other sectors of the country's economy, with the indicator that includes the volumes of exports and imports. The RCAi index 
(Revealed Comparative Advantage), that is, the index of revealed comparative advantage, unifies exports and imports of the i-th industry with total exports and imports of all industries of a particular country (McCall and Timothy, 1997):

$$
R C A_{i}=\left[\frac{X_{i}-M_{i}}{X_{i}+M_{i}}-\frac{\sum\left(X_{i}-M_{i}\right)}{\sum\left(X_{i}+M_{i}\right)}\right],
$$

where $R C A i$ - revealed comparative advantage of $i$-th industry; $X_{i}-$ cost of exports of the products of $i$-th industry; $M_{i}-$ cost of imports of the $i$-th industry.

A positive value of this index means that the $\mathrm{i}$-th industry has a comparative advantage. If the $\mathrm{i}$-th industry is a net exporter, then it exports more in comparison with the aggregate of all industries. A negative value of this index shows a comparative loss. The pattern of comparative advantages of Ukraine in foreign trade in separate groups of goods 2012-2017 is shown in Fig.1 and Tab. 1.

Pattern of comparative advantages of Ukraine in foreign trade in separate groups of agri-food products, 2012-2017

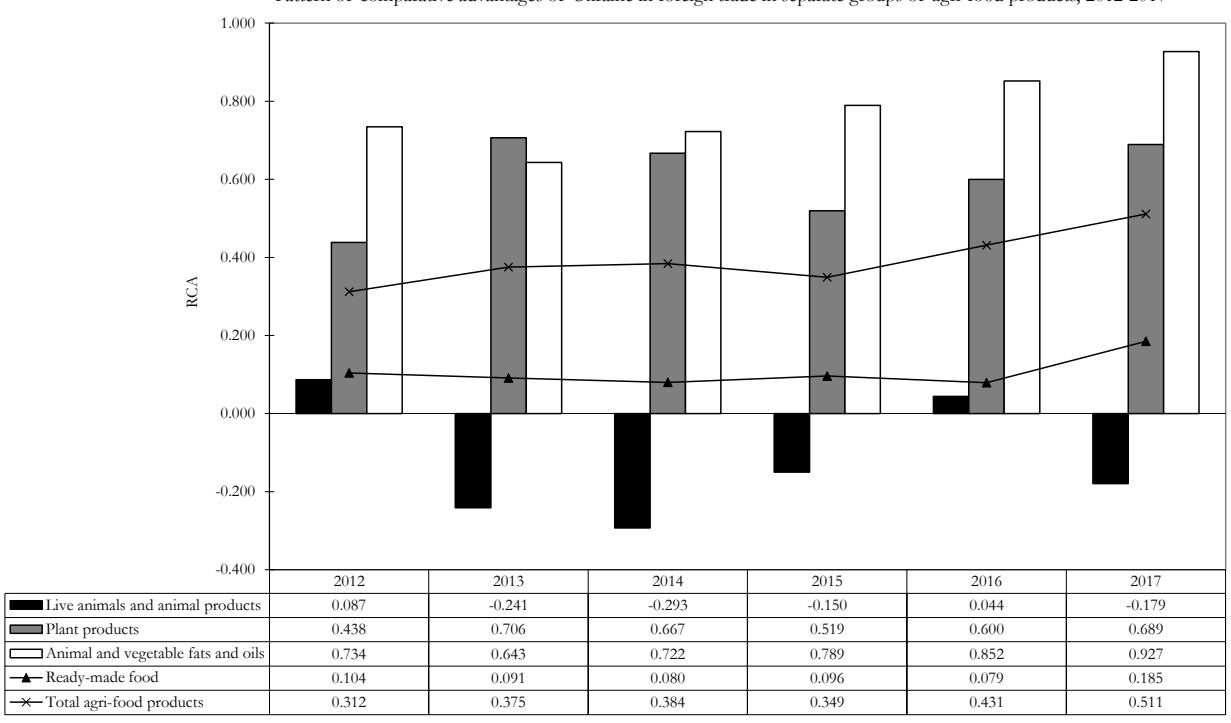

Fig. 1 - Pattern of comparative advantages of Ukraine in foreign trade in separate groups of agri-food products, 2012-2017. Source: compiled by the author

Tab. 1 - Comparative advantages of Ukraine in foreign trade in separate groups of goods,2012-2017. Source: compiled by the author on the basis of (Foreign Trade of Ukraine, 2018)

\begin{tabular}{|l|l|l|l|l|l|}
\hline \multicolumn{6}{|c|}{ RCA } \\
\hline 2012 & 2013 & 2014 & 2015 & 2016 & 2017 \\
\hline
\end{tabular}




\begin{tabular}{|c|c|c|c|c|c|c|}
\hline $\begin{array}{l}\text { 1. Live animals \& animal } \\
\text { products }\end{array}$ & 0.087 & -0.241 & -0.293 & -0.150 & 0.044 & -0.179 \\
\hline 2. Plant products & 0.438 & 0.706 & 0.667 & 0.519 & 0.600 & 0.686 \\
\hline $\begin{array}{l}\text { 3. Animal and vegetable fats } \\
\text { \& oils }\end{array}$ & 0.734 & 0.643 & 0.722 & 0.789 & 0.852 & 0.927 \\
\hline $\begin{array}{l}\text { Total agricultural products } \\
(1+2+3)\end{array}$ & 0.453 & 0.497 & 0.506 & 0.470 & 0.591 & 0.622 \\
\hline 4. Ready-made food products & 0.104 & 0.091 & 0.080 & 0.096 & 0.079 & 0.185 \\
\hline $\begin{array}{l}\text { Total agricultural products } \\
(1+2+3+4)\end{array}$ & 0.312 & 0.375 & 0.384 & 0.349 & 0.431 & 0.511 \\
\hline 5. Mineral products & -0.499 & -0.444 & -0.535 & -0.434 & -0.397 & -0.462 \\
\hline 6. Chemical industry products & -0.031 & -0.038 & -0.291 & -0.217 & -0.102 & -0.155 \\
\hline $\begin{array}{l}\text { 7. Polymer, plastic materials } \\
\text { and product made of them }\end{array}$ & -0.448 & -0.514 & -0.583 & -0.602 & -0.561 & -0.531 \\
\hline $\begin{array}{l}\text { 8. Unprocessed hides, cleaned } \\
\text { leather }\end{array}$ & 0.527 & 0.336 & 0.246 & 0.073 & 0.009 & -0.188 \\
\hline 9. Wood and wood products & 0.480 & 0.311 & 0.473 & 0.499 & 0.560 & 0.586 \\
\hline $\begin{array}{l}\text { 10. Wood or other material } \\
\text { mass }\end{array}$ & -0.227 & -0.233 & -0.192 & -0.195 & -0.154 & -0.128 \\
\hline $\begin{array}{l}\text { 11. Textile materials \& textile } \\
\text { goods }\end{array}$ & -0.097 & -0.240 & -0.263 & -0.376 & -0.300 & -0.428 \\
\hline $\begin{array}{l}\text { 12. Footwear, headwear, } \\
\text { umbrellas }\end{array}$ & -0.086 & -0.376 & -0.262 & -0.392 & -0.174 & -0.534 \\
\hline $\begin{array}{l}\text { 13. Stone, gypsum, cement } \\
\text { products }\end{array}$ & -0.366 & -0.353 & -0.313 & -0.297 & -0.262 & -0.207 \\
\hline $\begin{array}{l}\text { 14. Pearls, precious \& other } \\
\text { stones }\end{array}$ & -0.185 & -0.629 & -0.242 & -0.523 & -0.667 & -0.455 \\
\hline $\begin{array}{l}\text { 15. Non-precious metals and } \\
\text { products made of them }\end{array}$ & 0.731 & 0.746 & 0.722 & 0.698 & 0.684 & 0.669 \\
\hline $\begin{array}{l}\text { 16. Machines, equipment and } \\
\text { mechanisms }\end{array}$ & -0.257 & -0.235 & -0.043 & -0.098 & -0.215 & -0.201 \\
\hline 17. Means of transport & -0.323 & -0.352 & -0.083 & 0.023 & -0.028 & -0.047 \\
\hline 18. Instruments and devices & -0.561 & -0.547 & -0.346 & -0.481 & -0.482 & -0.505 \\
\hline 19. Various industrial goods & -0.142 & -0.273 & -0.166 & -0.163 & -0.113 & -0.147 \\
\hline
\end{tabular}

\subsection{Method for calculating index of actual comparative advantages $R C A_{i}$}

\section{for the assessment of agri-food production international competitiveness}

The above calculations of RCA indices show that agri-food industry in 2017 ranked third in terms of international competitiveness, when RCA index was 0.511 , following after non-precious metals and products made of the (RCA index $=0.669)$, wood and wood products (RCA index $=$ 0.586). Compared with 2012 , this industry ranked fourth in terms of international competitive- 
ness in the structure of all other industries $(\mathrm{RCA}$ index $=0.312)$, following non-precious metals and products made of them $($ RCA index $=0.731)$, unprocessed and cleaned hides $($ RCA index $=$ 0.527 ) and wood and wood products (RCA index $=0.480)$.

We shall emphasize that by the level of the revealed comparative advantages index agricultural products, whose RCA which in 2017 attained 0.622, rank second, but the low competitiveness of ready-made food products $(\mathrm{RCA}=0.185)$ had predetermined a lower competitiveness of agricultural products in general -0.511 . We shall also note that in the analyzed period of 2012-2017 (Fig. 1), we observe a negative tendency towards the gradual loss of competitiveness of the animal products and considerable fluctuations of comparative advantages of Ukraine in foreign trade in separate groups of agri-food products in different years of the period under study of 2012-2017.

Calculation of the above $\mathrm{RCA}_{\mathrm{ij}}$ index includes taking into account volumes of the world trade in all commodities and the world trade in products of a commodity group (in our case - agri-food products), that is the subject of the study. Bearing this in mind, such index shows more objectively international competitiveness of various countries in the trade in one or another type of commodities. We shall note that a positive value of $\mathrm{RCA}_{\mathrm{ij}}$ index indicates presence of competitive advantages of the country, and a negative value shows their absence. To this end, the greater value of this index is, the greater comparative advantages of this or that country are.

Using RCAij index, we calculated comparative advantages of separate countries in foreign trade in agri-food products which we can trace in Tab. 2.

Tab. 2 - Calculation of actual comparative advantages of separate countries of the world in agri-food products foreign trade, 2017. Source: compiled by the author on the basis of (European Commission, 2017)

\begin{tabular}{|l|l|r|r|r|r|r|}
\hline \multirow{2}{*}{ No } & \multirow{2}{*}{ Country } & $\begin{array}{r}\text { Export } \\
\text { AFP* }\end{array}$ & $\begin{array}{r}\text { Import } \\
\text { AFP* }\end{array}$ & Export & Import & \multirow{2}{*}{ RCA $_{\mathrm{ij}}$} \\
\cline { 3 - 6 } & & \multicolumn{3}{|c|}{ USD million } \\
\cline { 2 - 6 } 1. & EU countries (27) & 612939 & 623242 & 2167000 & 2301000 &.,- 038 \\
\hline 2. & Australia & 38405 & 14109 & 257000 & 261000 & 0.779 \\
\hline 3. & Argentina & 43151 & 2478 & 81000 & 69000 & 4.503 \\
\hline 4. & Belarus & 4455 & 4192 & 46000 & 46000 & 0.047 \\
\hline 5. & Brazil & 86435 & 13109 & 243000 & 233000 & 2.558 \\
\hline 6. & Egypt & 4738 & 17660 & 29000 & 69000 & -2.190 \\
\hline 7. & Israel & 42333 & 5916 & 63000 & 75000 & -0.419 \\
\hline 8. & India & 45023 & 20906 & 188000 & 190000 & 1.060 \\
\hline 9. & Indonesia & 5973 & 13989 & 104000 & 57000 & -0.827 \\
\hline 10. & Iran & 7653 & 4442 & 92000 & 45000 & 0.389 \\
\hline 11. & Kazakhstan & 62834 & 37909 & 455000 & 475000 & 0.445 \\
\hline 12. & Canada & & & & & 0.354 \\
\hline
\end{tabular}




\begin{tabular}{|l|l|r|r|r|r|r|}
\hline 13. & China & 66175 & 156823 & 2049000 & 1818000 & -0.389 \\
\hline 14. & Columbia & 6629 & 6395 & 60000 & 59000 & 0.033 \\
\hline 15. & Korea & 12628 & 33076 & 548000 & 520000 & -0.318 \\
\hline 16. & Malaysia & 33948 & 21435 & 227000 & 197000 & 0.490 \\
\hline 17. & Mexico & 22838 & 27076 & 371000 & 380000 & -0.094 \\
\hline 18. & New Zealand & 23979 & 4287 & 37000 & 38000 & 4.361 \\
\hline 19. & Norway & 9668 & 9009 & 161000 & 87000 & 0.044 \\
\hline 20. & UAE & 6544 & 16290 & 350000 & 230000 & -0.279 \\
\hline 21. & Russian Federation & 31597 & 41983 & 529000 & 335000 & -0.200 \\
\hline 22. & Saudi Arabia & 13456 & 29291 & 388000 & 156000 & -0.483 \\
\hline 23. & USA & 171909 & 141849 & 1546000 & 2336000 & 0.129 \\
\hline 24. & Turkey & 15671 & 16370 & 152000 & 237000 & -0.030 \\
\hline 25. & Ukraine & 18526 & 8036 & 69000 & 85000 & 1.131 \\
\hline 26. & Chile & 18907 & 6387 & 78000 & 79000 & 1.324 \\
\hline 27. & Switzerland & 9004 & 12894 & 226000 & 198000 & -0.152 \\
\hline 28. & Japan & 10859 & 93724 & 799000 & 886000 & -0.817 \\
\hline
\end{tabular}

*AFP - agri-food products

Calculations presented in Table 2 demonstrate that the greatest competitive advantages in 2017 had Argentine $\left(\mathrm{RCA}_{\mathrm{ij}}=4.503\right)$, New Zealand $\left(\mathrm{RCA}_{\mathrm{ij}}=4.361\right)$, Brazil $\left(\mathrm{RCA}_{\mathrm{ij}}=2.558\right)$, and Chile $\left(\mathrm{RCA}_{\mathrm{ij}}=1.324\right)$, which is explained by the great share of agri-food exports in the exports of goods of the said countries with the comparatively small volumes of food imports. We observe a somewhat different situation in Ukraine. We shall note that value of the index of actual comparative advantages here attains 1.131, which shows incidental comparative advantages of the national agricultural production in the world market, which we link with the average volume of imports of food products.

We shall note also, that in the course of study of the problem of competitiveness of the national agricultural production it was found that the latter has a higher international competitiveness than the agroindustrial production of Ukraine in general. Thus, the analysis of the data presented in Table 2, makes it possible to come to the following conclusions:

Firstly, there have been clearly identified the groups of countries showing a considerable amount of comparative advantages and their total absence. Among the countries that have no comparative advantages in foreign trade in agri-food products, it stands to mention the oil-producing countries of the Middle East (Iran and Saudi Arabia), whose index of actual comparative advantages $\mathrm{RCA}_{\mathrm{ij}}$ in 2017 was "minus" 0.827 and minus 0.483 respectively. Because of their climatic and natural conditions, they cannot provide themselves with food of their own production, while their considerable revenues from oil exports make it possible for them to import food products. We shall also include in the list of such countries Egypt, Israel, Japan, China and Korea.

Secondly, Russia should be ranked among the countries that show a lack of comparative advantages in agri-food production, since their share of imported food is much higher than exported food. 
Thirdly, the developed countries show either slight comparative advantages of their own agrifood production (USA, Canada, Norway), or the lack thereof, which in general is characteristic of the EU countries, since the value of their actual comparative advantages index in 2017 was $\mathrm{RCA}_{\mathrm{ij}}=-0.038$. This is explained by the fact that agri-food production is not the main field of export specialization of these countries and, accordingly, it represents a small share in their exports. However, from the standpoint of physical volumes of their food exports, these countries hold an important place in the world exports of these products.

\subsection{Study of the pattern of international competitiveness of separate food products using indices of relative trade advantages RTA $_{i j}$}

Aside from the assessment of international competitiveness of the national agri-food production in general, we also conducted a study of the pattern of international competitiveness of separate food products in Ukraine for the years 2015-2017. For our analysis, we selected the goods that today appear to be the basis of Ukrainian agri-food exports: grain (wheat, barley, corn), sunflower seeds and sunflower oil, beef, milk products (margarine and non-fat milk powder). To this end we chose the method of calculating indices of relative trade preferences RTAij for certain agricultural products that are the main commodities of export for Ukraine. The chosen period of 2015-2017 allows tracing the pattern of changes in the competitiveness of separate products over time. We shall note that for calculation of the relative trade advantages index RTAij, export and import indices for a particular product are used as is shown in the following formula (McCall and Timothy, 1997):

$$
R T A_{i j}=R X A_{i j}-R M P_{i j} \text {, }
$$

where $R X A_{i j}$ - index of relative export competitiveness of $i$-th commodity in $\mathrm{j}$-th country; $R M P_{i j}$ - relative import penetration index of $i$-th commodity in $j$-th country. A positive value in this index indicates relative advantages in foreign trade, while a negative value indicates relative shortcomings.

The index of relative export competitiveness of $R X A_{i j}$ is calculated using the following formula (McCall \&Timothy, 1997):

$$
R X A_{i j}=\left(X_{i j} / \sum_{l, l \neq j} X_{i l}\right) /\left(\sum_{k, k \neq i} X_{k j} / \sum_{k, k \neq i} \sum_{l, l \neq j} X_{k l}\right)
$$

where $X$ - cost of export; $i$ and $k$-goods; $j$ and $l$ - countries.

In other words, the $R X A_{i j}$ index is determined as the ratio of the country's share in the world export of a certain commodity to the share of this country in world export of all other commodities. A specific feature of such a measure is that the world commodity exports are always determined as the sum of exports of all countries with the exception of the country under study, while the value of exports of the commodity under study is subtracted from the sum of the world exports. This helps to avoid a double count, i.e. the export of the country (commodity) is both a numerator and a component of the denominator. This aspect is especially relevant when the product under study represents a considerable share of the world exports. 
The value of the $\mathrm{RX} A_{i j}$ index is interpreted as follows: if it exceeds 1 , the country has comparative advantages in terms of exports of the commodity in question study; if $\mathrm{RX} A<1$, this indicates a competitive disadvantage.

Relative import penetration index, $R M P_{i j}$ is very similar to $R X A_{i j}$, with the only difference being that here imports are taken into account (McCall and Timothy, 1997):

$$
R M P_{i j}=\left(M_{i j} / \sum_{l, l \neq j} M_{i l}\right) /\left(\sum_{k, k \neq i} M_{k j} / \sum_{k, k \neq i} \sum_{l, l \neq j} M_{k l}\right)
$$

If the value of $R M P_{i j}$ index exceeds 1, import penetration is high (competitive shortcomings are indicated), if it is less than 1 - import penetration is low (i.e. a competitive advantage exists).

\section{RESULTS AND DISCUSSION}

From our analysis of international competitiveness of commodities forming the basis of agrifood exports of Ukraine in 2015-2017 (Fig. 2) (based on the calculations of the indices of relative trade advantages $R T A_{i j}$ ), several important conclusions can be put forward. Firstly, a positive fact is that throughout the period of 2015-2017, all the commodities selected for the study with the exception of non-fat milk powder in 2015, were competitive in the external market, as evidenced by the positive values of the RTA indices.

Secondly, as we see in Fig. 2, for nearly all food products except for corn and non-fat dry milk, there has been a considerable decline in competitiveness in 2017 compared with 2016. This was caused by the shrinkage of exports resulting from the military hostilities between Ukraine and the Russian Federation, a situation that impaired relations between the countries in the sphere of international trade. For example, in 2017 compared with 2016, the RTA index for wheat fell by 0.618 ; for barley - by 10.791 ; sunflower oil - by 5.859 ; beef - by 0.193 ; margarine - by 0.269 , etc. This shows a rather high degree of dependence of Ukraine on the external markets situation and thus the need for finding the ways of exports diversification.

Thirdly, our analysis of the values of RTA index shows that in 2015-2017, sunflower oil was the most competitive product in the world market, since its share of Ukrainian exports was ten times greater than a similar share in the world exports (RTA in 2017 amounted to 30.298). Barley and sunflower seeds are also quite competitive. It should be noted that in 2016 the RTA value for barley was 14.361 .

Fourthly, the calculated indices of relative trade advantages of RT $A_{i j}$ for grains in 2015-2017 indicate the competitiveness of Ukraine regarding this commodity. Although grain exports account for the largest share in the Ukrainian agricultural exports, the absolute RTA value is rather low. For example, in 2017, the RTA index for wheat was 1.458, for barley and corn -3.570 and 4.589, respectively. This is explained by the fact that along with exports in the period under study, Ukraine continuously imported certain types of grain. Aside from this, grain is characterized by a fairly large share of world exports. 


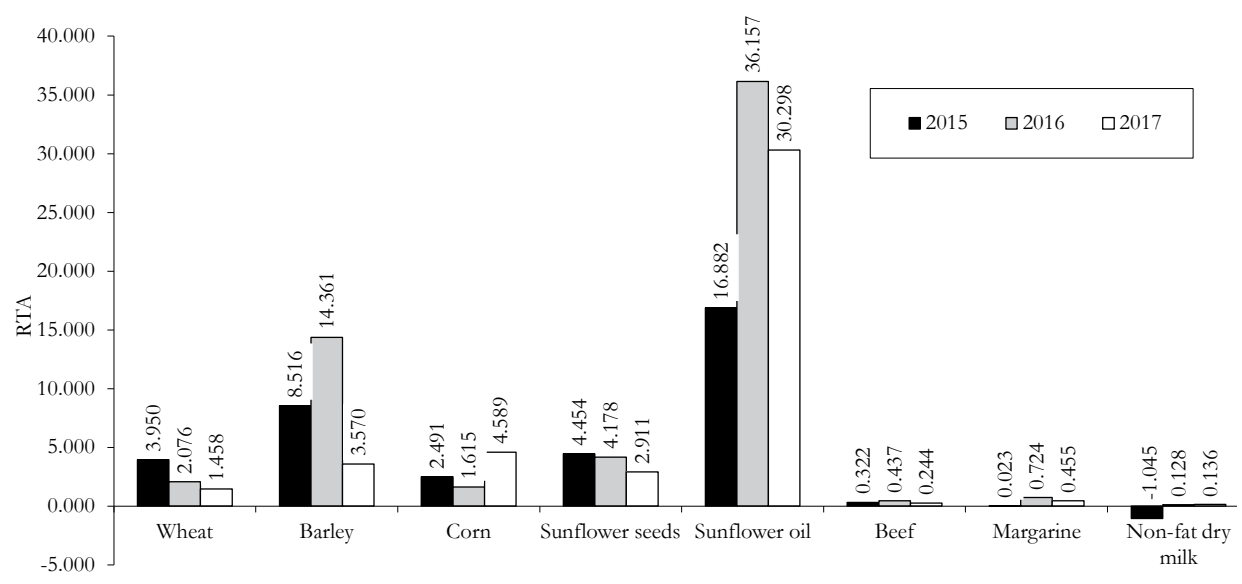

Fig. 2 - Pattern of international competitiveness of the goods prevailing in agri-food export of Ukraine, 2015-2017 (based on the calculations of relative trade advantages indices RTAij). Source: compiled by the author on the basis

$$
\text { of (FAOSTAT, 2017) }
$$

Fifthly, in Fig. 2 we can clearly trace the tendency of low competitiveness regarding animal products. Nevertheless, a positive fact is that in 2017 all the three products under study (beef, margarine and non-fat milk powder) were competitive in the foreign market. It is not correct to regard considerable fluctuations in the volumes of exports in various years as a positive phenomenon, as Ukraine does not have a solid position in the world market for these commodities. At any rate, in most cases competitiveness regarding these products is of a price-related nature and depends to a great extent on the situation in foreign markets.

\section{CONCLUSIONS AND RECOMMENDATIONS IN THE CON- TEXT OF IMPROVING COMPETITIVENESS OF UKRAINIAN FOOD PRODUCTION WITHIN WORLD MARKETS}

Bearing in mind the above mentioned issues as well as the positive foreign experience, it seems expedient to implement measures in the context of increasing competitiveness of the national food products in the world markets in the following key areas (Senyshyn, 2014):

1. Boosting export potential of the national producers of agricultural products by way of:

- extension of the commodity structure of food products exports and support of the food groups with increasing volumes of export (sugar and confectioneries, cocoa, ready-made grain products, etc):

- assistance in the development and introduction of quality management systems based on the principles of ISO 9000, food safety management systems (HACCP) and environment protection systems based on the principles of ISO 14000; 
- the establishment of a national agency for the international marketing of agricultural products under the Ministry of Agrarian Policy and Food of Ukraine, the functions of which would include a strategic and active study of the situation in external markets, the organization of international marketing, as well as a search for foreign partners for cooperation;

- increase in the state strategic reserves of certain food products (grain, sugar, etc.) for the state interventions and, consequently, for easing the price fluctuations and prevention of speculation in the domestic market.

2. Using the positive experience of the EU countries in the regulation of the agri-food products market towards strengthening competitiveness of the food complex that would encompass:

- the establishment of a joint program to attract leading European specialists to cooperate with Ukrainian partners in the field of establishing rules for the regulation of the internal agri-food market in accordance with European and international standards;

- implementation on the territory of Ukraine of EU-supported projects, the objective of which will be to help organize internships, seminars and conferences; support of cross-border contacts, dissemination of information on European grant programs among Ukrainian producers and exporters of agrarian products;

- ensuring Ukraine's food security through the mechanisms of financial support of the farmers by paying subsidies to them depending on the area of the farming land and livestock number.

3. Harmonization of the national standards for agricultural and agri-food products in accordance with EU standards in the following principal ways:

- the establishment and introduction of a national base harmonized with international requirements standards for agricultural and food products and raw materials, as well as providing the required amounts of financing for these works;

- the introduction of a Special Accession Program for agriculture and rural development (SAPARD) on the territory of Ukraine that will facilitate the harmonization of Ukrainian standards with the requirements of the EU with lower expenditures from the state budget.

4. Strengthening cooperation of the farms of population-producers of agricultural commodities by establishing a state agency for the development of cooperatives, the objectives of which will be: the stimulation of the cooperative movement in the country by rendering legal assistance in the form of consultations to cooperating organizations; providing recommendations to government agencies on issues of cooperation; the elaboration of economic projects that can be implemented on these cooperative principles.

5. Establishing cooperation between the producers of agricultural commodities and research institutions through the introduction of grant programs in higher educational institutions in order to support university research projects aimed at the resolution of problems of the food industry along with the support of young scientists. 


\section{References}

1. Andriychuk, V. G. (1990). Improving the efficiency of agro-industrial production. Kyiv: Urozhay.

2. Chaudhary, A. (2016). Revealed Comparative Advantage Index: An Analysis of Export Potential of Indian Textiles Industry in the Post MFA Period. American Journal of Economics, 6(6), 344-351. https://doi.org/10.5923/j.economics.20160606.05

3. Danylyshyn, B. M. (2008). Scientific essays on economy of the use of natural resources. Kyiv: RVPS Ukrainy NAN Ukrainy.

4. Dejneko, L. V., \& Cymbaljuk, A. V. (1998). Efficiency of food industry development in the region. Irpinj: IFEI.

5. Dejneko, L. V., Kovalenko, A. O., \& Korenjuk, P. I. (2007). Ukraine's food complex: the state and prospects of development: [monograph]. Kyiv: Naukova dumka.

6. Dolishnij, M. I., Topikha, V. I., Buljuk, V. V., \& Romanova, V. A. (2006). Ukraine's food market in the WTO: [monograph]. Mykolajiv: MDAU.

7. European Commission (2017). Agriculture and rural development. International Trade Statistics. Factsheets on EU28 agri-food trade with the world, individual countries and selected regions, European Commission. Retrieved September 03, 2018, from: https:// ec.europa.eu/agriculture/trade-analysis/statistics_en\#countries-top.

8. FAOSTAT (2017). Food and Agricultural Organization of the United Nation. FAOSTAT. Retrieved October 19, 2018, from: http:// faostat3. fao. org/ faostatgateway /go/ to/ download/ T/TP/E.

9. Granabetter, D. (2016). Revealed Comparative Advantage Index: An Analysis of Export Trade in the Austrian District of Burgerland. Review of Innovation and Competitiveness: A Journal of Economic and Social Research, 2(2), 97-114.

10. Hubenko, V. (2003). Mekhanizm zrostannia konkurentospromozhnosti tovariv APK na svitovomu rynku [The mechanism of increasing the competitiveness of agricultural products in the world market]. Abroinkom, 1-2, 58-62.

11. Institute of Organic Agriculture (FiBL) (2016). Organic Agriculture in Europe 2013. BIO AUSTRIA Round Table at BioFach. Retrieved December 14, 2018, from: http:// images. derstandard. at/2016/ 02/ 19/ Bio_Daten.pdf

12. Kohls, R. L., \& Uhl, J. N. (1990). Marketing of agricultural products, 7th ed., Macmillan Publishing Company, New York, USA; Collier MacMillan publishers, London, UK.

13. Kolkova, A. (2018). Indicators of Technical Analysis on the Basis of Moving Averages as Prognostic Methods in the Food Industry. Journal of Competitiveness, 10(4), 102-119. https:// doi.org/10.7441/joc.2018.04.07

14. Kyryljuk, J. M. (2009). Current state and ways of ensuring food safety of Ukraine. Bulletin of Cherkasy University. Economic sciences, 36 (1), 49-58.

15. Majovecj, J. (2006). Agrarian Entrepreneurship in Ukraine. Lviv: Publishing house of Lviv Ivan Franko National University.

16. Majstro, S. V. (2005). The directions of state support to the agrarian sector and its impact 
on the competitiveness of products in the world market. Retrieved January 08, 2019, from: http:// www. academy. gov.ua /ej/ ej2/txts/galuz/05msvpsr.pdf

17. McCall, A., \& Timothy, J. (1997). Agriculture Policies and World Markets. New York, USA; Collier MacMillan publishers, London, UK.

18. Paskhaver, B. (2001). Food availability. Ekonomika Ukrajiny, 7, 69-77.

19. Sabluk, P. T., Bilous, O. Gh., \& Vlasov, V. I. (2008). Globalization and food industry. Kyiv: NNC IAE.

20. Scott, L., \& Vollrath, T. L. (1992). Global Competitive Advantage and Overall Bilateral Complementary in Agriculture: Statistical Review. United States Department of Agriculture, Economic Research Service. Statistical Bulletin, 850, 111-123.

21. Senyshyn, O. S. (2014). Directions of increasing the competitiveness of domestic food products in world markets. Scientific Bulletin of the Kherson State University, 6(2), 58-60.

22. State Statistics Service of Ukraine (2018). Foreign Trade of Ukraine. Statistical yearbook. State Statistics Committee of Ukraine. Kyiv, Ukraine.

23. State Statistics Service of Ukraine (2018). Foreign trade of Ukraine in goods and services in 2017. Statistical yearbook. State Statistics Committee of Ukraine. Kyiv, Ukraine.

24. Suchanek, P., \& Kralova, M. (2018). The Influence of Costumers' Personal Characteristics on their Satisfaction with the Food Industry. Journal of Competitiveness, 10(4), 151-170. https://doi.org/10.7441/joc.2018.04.10

25. The FiBL-IFOAM Survey (2016). The World of Organic Agriculture 2015-2016: Overview Table. FiBL \& IFOAM. Retrieved September 28, 2018, from: http://www.organic-world. net/ fileadmin/ documents/yearbook/2016/web-fibl-ifoam-2013-318-321.pdf

26. United State Department of Agriculture (2009). The European Union's Common Agricultural Policy: Pressures for Change. International agriculture and trade reports, WRS2009-2, 5 .

27. WTO (2016). Annual Report 2016. International Trade Statistics. WTO Organization. Retrieved from: www. wto.org/ english/ res_e/ statis_e/ its2016_e/stats2013_e.pdf

\section{Contact information}

prof. Oksana Senyshyn, Doctor of Economics

Ivan Franko National University of Lviv

Faculty of Economy, Department of Management

Ukraine

E-mail:Okssenyshyn@gmail.com

ORCID: 0000-0002-5089-2591

prof. Oleksandr Kundytskyj, Doctor of Economics

Ivan Franko National University of Lviv

Faculty of Economy, Department of Management

Ukraine

E-mail:skund@ukr.net

ORCID: 0000-0002-7848-4717 assistant of prof. Olha Klepanchuk, Ph.D.

Lviv Trade and Economic University

Faculty of Economy

Department of Theoretical and Applied Economics

Ukraine

E-mail: o.klepanchuk@gmail.com 